\title{
Kinematic Analysis of the Dam and Powerhouse Sites of the Baglihar Hydropower Project
}

\author{
Romesh Kumar, G. M. Bhat, Yudhbir Singh, Arjun Singh, Ahsan Ul Haq
}

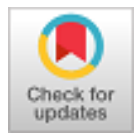

\begin{abstract}
The present study assesses the slope stability at the most significant Baglihar Dam for slope failure and landslides occurrences. The study comprises of twelve sites which were selected for detailed geotechnical investigation for assessment of potential slope failures using basic Rock Mass Rating (RMRb), Slope Mass Rating (SMR) and kinematic analysis techniques. The results show that even though the rocks are of fair quality but other factors including joint pattern and density caused by tectonic and anthropogenic activities have rendered three sites completely unstable, 8 sites are unstable and one site is stable. Moreover Nine sites are susceptible to wedge failure, six to topple and two to plane failure. The RMRb value varies from 45 to 55 and SMR value varies from 11 to 44 . The thorough results and interpretation of work done is presented in this paper.
\end{abstract}

Key words: Baglihar Dam, RMRb, SMR, Kinematic Analysis.

\section{INTRODUCTION}

The 450 MW (3 x 150 MW) Baglihar Hydro-Electric Project Stage-II is one of the major run of river hydel schemes on Chenab river, in Jammu and Kashmir. The project is located in the Ramban District of Jammu province on Jammu-Srinagar Highway (NH44), 150 km from Jammu city. The dam site and the powerhouse area comprises of highly sheared and foliated metamorphic rocks. Due to high seismic activity in the Himalayan region the slopes along the river valleys are at more risk to slope failures and landslides (Parvaiz, 2012; Gupta and Shah, 2008; Sundriyal, 2007; Singh, 1974, etc.). The landslide incidence is frequent phenomenon in the tectonically and seismically active areas (Bolt et al., 1975). The rocks present in the reservoir area of the Baglihar dam site are fragile and lie within the Panjal Thrust Zone (Singh, 2012). The study area falls in the zone between Murree Thrust in the south and Panjal Thrust in the north. The rocks are highly jointed and marked by number of shear zones. Outcrops of the rocks occur along the recently cut slopes of the road constructed leading to the dam site and are susceptible to mass flows. The present study was undertaken to assess stability of the slopes on the downstream part of the dam.

Revised Manuscript Received on January 30, 2020.

* Correspondence Author

Romesh. Kumar, Department of Geology, University of Jammu, Jammu, India. India.

G. M. Bhat, Department of Geology, University of Jammu, Jammu, India.

Arjun Singh, Department of Geology, University of Jammu, Jammu, India.

Ahsan Ul Haq*, Department of Geology, University of Jammu, Jammu, India. E-mail: ahsanmalik4uly@gamil.com

(C) The Authors. Published by Blue Eyes Intelligence Engineering and Sciences Publication (BEIESP). This is an open access article under the CC-BY-NC-ND license http://creativecommons.org/licenses/by-nc-nd/4.0/
For this purpose, kinematic analysis was undertaken at twelve sites and the data collected was analysed and interpreted along with field observations.

\section{STUDY AREA}

The study area (Fig. 1) falls in the Lesser Himalaya and covers part of Ramban and Doda districts along the National Highways-Jammu-Srinagar (NH44) and Jammu-Kishtwar (NH1B) between latitudes $\mathrm{N} 32^{\circ} 60^{\prime}$ \& N $32^{\circ} 40^{\prime}$ and longitudes $\mathrm{E} 75^{\circ} 40^{\prime} \& \mathrm{E} 75^{\circ} 60^{\prime}$. The Dam site lies on river Chenab between Batote town and Ramban near Pira on the NH44 whereas the reservoir area lies along the JammuKishtwar Highway covered in the Survey of India toposheets $43 \mathrm{O} / 8, \mathrm{O} / 15$ and $\mathrm{O} / 16$.

The area experience annual average rainfall of $1209 \mathrm{~mm}$ with tropical to temperate climatic conditions having average temperature of $21.1^{0} \mathrm{C}$. The sites are located in deep gorge (Fig.2d) with rugged terrain having steep slopes (ranging from $45^{\circ}-70^{\circ}$ ). The study area comprises of quartzites, slates and phyllites having general trend of ENEWSW with dip of $65-70^{\circ}$ towards SSW.

The valley slopes and the drainage are structurally controlled. A number of terrace deposits of river Chenab are present at different levels on both the banks. The left bank area of the dam with the infrastructure is located in a part of a large amphitheatre of rock and debris slides.

The Dam is located on a competent quartzite band although the abutments are standing on relatively sound but highly jointed quartzite.

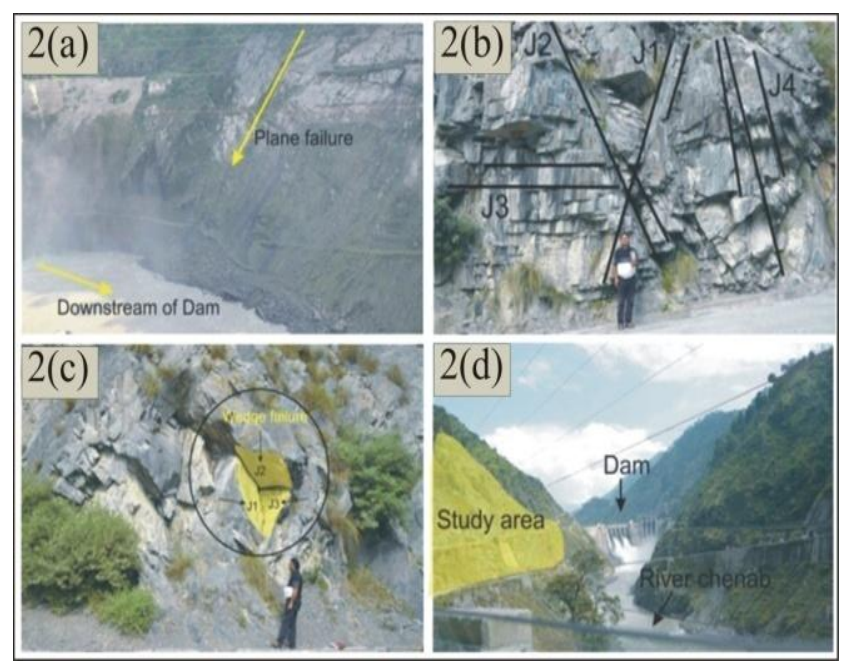

Fig.1: Map showing the location of study area.

Published By:

Blue Eyes Intelligence Engineering

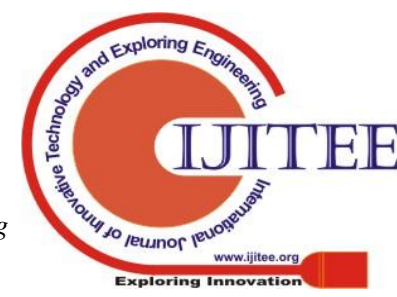




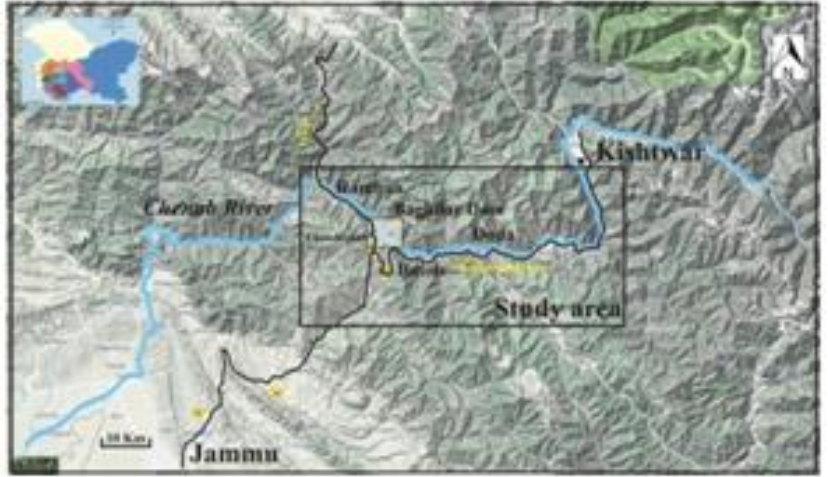

Fig.2: Representative Field photographs at and downstream of the dam site.

\section{METHODOLOGY}

The geotechnical investigation carried out in present study is based on conventional approaches. The work is based on the detailed field investigation to prepare detailed inventory of landslides present in the Dam site. The landslides have been characterized in term of mode of failure with the help of geotechnical parameters and detailed field investigations. Bieniawski, 1989 Basic rock mass rating method and Romana, 1985 Slope mass rating method together with Hoek and Bray (1981) Kinematic analysis practice was followed in this study. On the basis of introductory survey, 12 potential failure sites were chosen in the study area. In the current work RQD was calculated from volumetric joint count, which is the sum of number of joints per cubic meter anticipated by Palmstrom (2005). The following parameters were estimated for Rock mass rating: (a) Uniaxial compressive strength (b) Rock quality designation (RQD) (c) Spacing of discontinuities (d) Condition of discontinuities (e) Ground water condition. The SMR was calculated by adding bRMR rating with adjustment factors in addition to the method of slope excavation. The formula for Slope mass rating is:

$\mathrm{SMR}=$ bRMR $(\mathrm{F} 1+\mathrm{F} 2+\mathrm{F} 3)+\mathrm{F} 4$.

The common universal trait of rock mass is the occurrence of discontinuity planes including bedding planes, fractures, observed in field are developed after a major tectonic event or during upliftment of rocks (Prince, 1966). The most common types of failures which occur in rock slope are planar, wedge and topple which tend to occur along the structural discontinuities i.e. joints. To analyze potential slope failures it is important to study various joint parameters like joint planes, joint aperture, joint density, joint persistence and joint spacing, etc. In the current study, the data collected on joints is given in Table 1 and are graphically projected on stereographic projections which are used to know possible mode of failure and direction of failure (Hoek and Bray, 1981 and Goodman, 1989). This method compares the orientation of rock discontinuities and internal angle of friction of the rock to see which fractures/joints/bedding planes render the rock mass theoretically unstable. joints, faults and foliations. The majority of discontinuities

\section{GEOLOGICAL SETTING}

The study area is represented by linear zone of rocks as Para-autochthonous belt flanked by two major tectonic planes i.e., the Murree Thrust in the south and the Panjal Thrust (Fig. 3) in the north (Wadia, 1931). The oldest but poorly exposed rock unit in this belt is the Sauni volcanics, which is composed of basalt-orthoquartzite assemblage juxtaposed against the Murrees in the south along the Murree Thrust. The younger Lesser Himalayan rocks in this area i.e, Sincha Formation are thrusted over by the older Salkhala Formation against PT (Jangpangi et al., 1986). The reservoir area between Ramban and Doda is composed of highly tectonised rock succession exposed along the NH1B from Pira towards Ramban in the southwest to Doda in the northeast is divisible into two distinct formations i.e., Gamir Formation and the overlying Baila Formation. The Gamir Formation consists of creamy white quartzites, gritty quartzites with band of conglomerate, ferruginous quartzites, calcareous flaggy quartzites, massive quartzites and purple shales of Precambrian age. The Baila Formation is composed of greenish grey, laminated and jointed calcareous shales with lenticles of limestone and black to carbonaceous phyllites and slates. The Baila and Gamir formations are in faulted contact with the Ramban Formation (Ramban Slates of Bhatia and Bhatia, 1973). The Ramban Formation comprises of phyllitic and calcareous slates intercalated with the limestone. The other rock formations present in the area include: Sauni, Bhimdasa formations, Murree Group of rocks and Siwaliks. The Bhimdasa Formation consists of shale-slate to pebbly phyllites with bands of quartzites. The Murrees are composed of alternation of sandstone, shale and claystones of Middle Eocene to Oligocene age, whereas the Quaternary Siwaliks are composed of friable to massive sandstones, mudstones and, pebble and boulder conglomerates. Further south of the study area the Murrees are thrusted over the Siwalik Group against the Main Boundary Thrust. The area is affected by series of faults, folds and thrusts resulting in repetition of the stratigraphic succession.

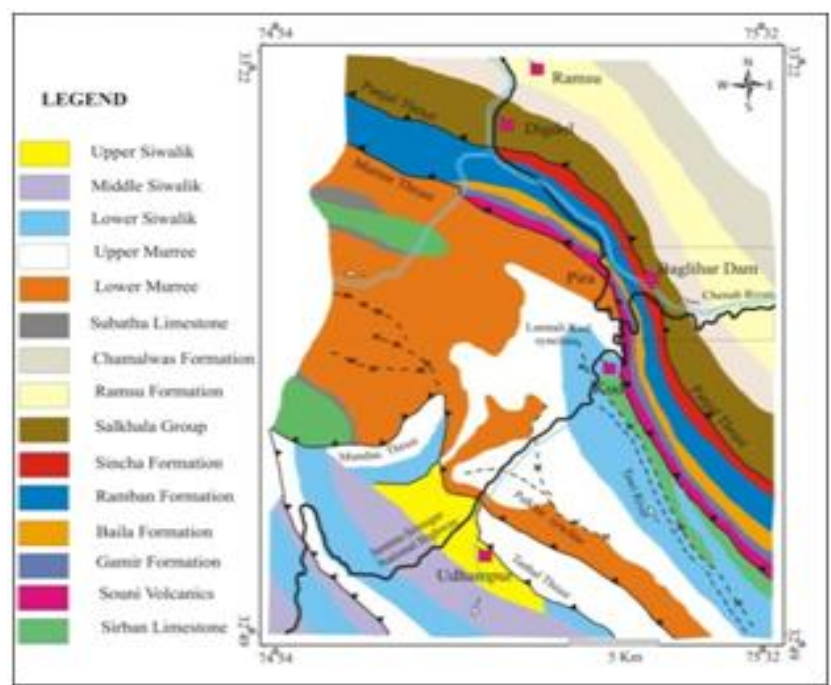

Fig.3: Geological map of the study area after Singh Yudhbir 2006).

Published By:

Blue Eyes Intelligence Engineering

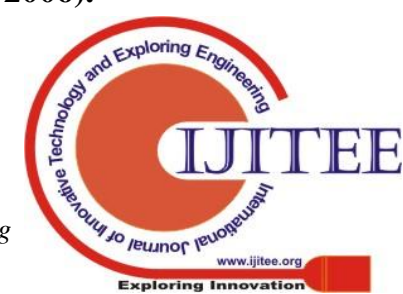




\section{RESULT}

The selected twelve sites for investigation are located at the right bank of Chenab River, downstream of the dam site near tail track area. Detailed joint and slope data required was collected at these sites whose details are given in Table 1. Our study reveals that all the 12 sites have few common characteristics which are: (a) All sites have same rock type i.e. phyllitic quartzite (b) Joint walls are smooth in nature and slightly to moderately weathered (c) The slopes are dry in nature. Other observations made on the selected sites (S1 to S12) are briefly described here:

\section{S1:}

At this site volumetric joint count is 18 and the RQD estimated from the volumetric joint count is $56 \%$. The spacing of the joints on an average ranges from $3-30 \mathrm{~cm}$. The joint walls have an aperture ranging from $0-8 \mathrm{~mm}$. The calculated RMR value for this site is 45 that falls under fair rock quality. Kinematic analysis of discontinuity planes and their intersections (Fig. 4) with respect to slope face indicates that there is possibility of wedge failure by the intersection of joint planes $55^{\circ} / \mathrm{N} 65^{\circ} \mathrm{E}$ (J1) and $67^{\circ} / \mathrm{N}$ (J3). The SMR Value calculated from the potential failure of planes is 20. According to SMR Classification, the rock mass of the site is very bad and completely in unstable condition. The site falls in Class $\mathrm{V}$ and the probability of failure is $90 \%$.

\section{S2:}

The volumetric joint count at this site is 19-29 and the RQD estimated from the volumetric joint count is $19-52 \%$. The spacing of the joints on an average ranges from $5-50 \mathrm{~cm}$. The joint walls have an aperture ranging from $0-10 \mathrm{~mm}$. The calculated RMR value for this site is 48 that falls under fair their intersections (Fig. 4) with respect to slope face indicates that there is possibility of wedge failure by the intersection of joint planes $55^{\circ} / \mathrm{N} 65^{\circ} \mathrm{E}$ (J1) and $67^{\circ} / \mathrm{N}$ (J3). The SMR value calculated from the potential failure planes is 40. According to SMR Classification the rock mass of the site is bad and in unstable condition. The site falls in Class IV and the probability of failure is $60 \%$.

\section{S3:}

At this site the calculated volumetric joint count is $15-27$ and the RQD estimated from the volumetric joint count is $26-65 \%$. The spacing of the joints on an average ranges from $3-150 \mathrm{~cm}$. The joint walls have an aperture ranging from $0-12 \mathrm{~mm}$. The calculated RMR value for this site is 55 that falls under fair rock quality. Kinematic analysis of discontinuity planes and their intersections (Fig. 4) with respect to slope face indicates that there is possibility of planar failure along joint plane 54\% N180 (J3). The SMR value calculated from the potential failure of planes is 12 . According to SMR Classification the rock mass of the site is very bad and in completely unstable condition. The site falls in Class $\mathrm{V}$ and the probability of failure is $90 \%$.

\section{S4:}

At this site, the volumetric joint count is 20-30 and the RQD estimated from the volumetric joint count is $16-49 \%$. The spacing of the joints on an average ranges from $2-120 \mathrm{~cm}$. rock quality. Kinematic analysis of discontinuity planes and

The joint walls have an aperture ranging from 0-12 mm. The calculated RMR value for this site is 50 that falls under fair rock quality. Kinematic analysis of discontinuity planes and their intersections (Fig. 4) with respect to slope face indicates that there is possibility of wedge failure by the intersection of joint planes $62^{\circ} / \mathrm{N} 80^{\circ} \mathrm{W}(\mathrm{J} 2)$ and $61^{\circ} / \mathrm{S} 10^{\circ} \mathrm{W}$ (J3) and toppling failure along Joint plane $58^{\circ} / \mathrm{N} 70^{\circ} \mathrm{E}$ (J1). The SMR value calculated from the potential failure of planes is 1 and 40. The average value of SMR for the site is 20.5. According to SMR Classification the rock mass of the site is bad and in unstable condition The site falls in Class IV and the probability of failure is $60 \%$.

\section{S5:}

The volumetric joint count calculated at this site is 18-27 and the RQD estimated from the volumetric joint count is $26-56 \%$. The spacing of the joints on an average ranges from $4-100 \mathrm{~cm}$. The joint walls have an aperture ranging from $0-12 \mathrm{~mm}$. The calculated RMR value for this site is 53 that falls under fair rock quality. Kinematic analysis of discontinuity planes and their intersections with respect to slope face indicates that there is possibility of wedge failure by the intersection of joint planes $45^{\circ} / \mathrm{N} 70^{\circ} \mathrm{W}(\mathrm{J} 2)$ and $52^{0} \%$ $\mathrm{S} 10^{0} \mathrm{~W}(\mathrm{~J} 3)$. The SMR value calculated from the potential failure of planes is 21.6. According to SMR Classification the rock mass of the site is bad and in unstable condition, and falls in Class IV with probability of failure of $60 \%$.

\section{S6:}

At this site, the volumetric joint count is 18-27 and the RQD estimated from the volumetric joint count is $26-56 \%$. The spacing of the joints on an average ranges from 7-100 cm. The joint walls have an aperture ranging from $0-12 \mathrm{~mm}$. The calculated RMR value for this site is 48 that falls under fair rock quality. Kinematic analysis of discontinuity planes and their intersections with respect to slope face indicates that there is possibility of wedge failure by the intersection of joint planes $76^{\circ} / \mathrm{S} 05^{\circ} \mathrm{W}$ (J3) and $50^{\circ} / \mathrm{S} 45^{\circ} \mathrm{W}$ (J4) and toppling failure along joint plane $54^{0} / \mathrm{N} 75^{\circ} \mathrm{E}$ (J1). The SMR value calculated from the potential failure of planes is 25.6 and 37. The average value of SMR for the site is 31.3. According to SMR Classification the rock mass of the site is in bad condition and unstable, and the site falls in Class IV and the probability of failure of $60 \%$.

\section{S7:}

The volumetric joint count at this site is 25-33 and the RQD estimated from the volumetric joint count is 6-33\%. The spacing of the joints on an average ranges from 3-40 cm. The joint walls are smooth in nature and slightly to moderately weathered. The joint walls have an aperture ranging from $0-10 \mathrm{~mm}$. The calculated RMR value for this site is 51 that falls under fair rock quality. Kinematic analysis of discontinuity planes and their intersections with respect to slope face indicates that there is possibility of wedge failure by the intersection of joint planes $68^{\circ} / \mathrm{N} 70^{\circ} \mathrm{W}$ (J2) and $60^{\circ} / \mathrm{S}$ (J3) and toppling failure along Joint plane $68^{\circ} / \mathrm{N} 60^{\circ} \mathrm{E}(\mathrm{J} 1)$. The SMR value calculated from the potential failure of planes is 15.3 and 42.

Published By:

Blue Eyes Intelligence Engineering

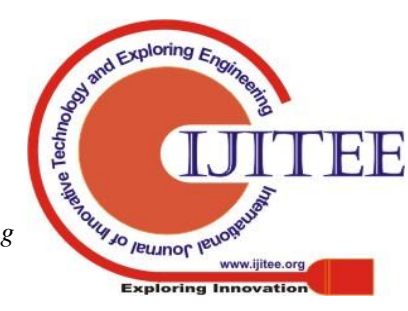


The average value of SMR for the site is 28.65. Rock mass of the site is in bad condition and unstable. The site falls in Class IV and the probability of failure is $60 \%$.

\section{S8:}

The volumetric joint count at this site is 17-25 and the RQD estimated from the volumetric joint count is 33-59\%. The spacing of the joints on an average ranges from $12-80 \mathrm{~cm}$. The joint walls are slightly rough to smooth in nature and slightly to moderately weathered. The joint walls have an aperture ranging from $0-10 \mathrm{~mm}$. The calculated RMR value for this site is 51 that falls under fair rock quality. Kinematic analysis of discontinuity planes and their intersections (Fig. 4) with respect to slope face indicates that there is possibility of wedge failure by the intersection of joint planes $68^{\circ} / \mathrm{N} 70^{\circ} \mathrm{W}(\mathrm{J} 2)$ and $60^{\circ} / \mathrm{S}(\mathrm{J} 3)$ and toppling failure along joint plane $68^{\circ} / \mathrm{N} 60^{\circ} \mathrm{E}$ (J1). The SMR value calculated from the potential failure of planes is 15.3 and 42 with an average of 28.65. The rock mass of the site is in bad condition and unstable. The site falls in Class IV and the probability of failure is $60 \%$.

\section{S9:}

The volumetric joint count is 25-33 and the RQD estimated from the volumetric joint count is $6-33 \%$. The spacing of the joints on an average ranges from $3-40 \mathrm{~cm}$. The joint walls have an aperture ranging from $0-10 \mathrm{~mm}$. The calculated RMR value for this site is 45 that falls under fair rock quality. Kinematic analysis of discontinuity planes and their intersections with respect to slope face indicates that there is possibility of toppling failure along $74^{\circ} / \mathrm{N} 60^{\circ} \mathrm{E}$ (J1). The SMR value calculated from the potential failure of planes is 35. The rock mass of the site is in bad condition and unstable and the site falls in Class IV with probability of failure of $60 \%$.

\section{S10:}

The volumetric joint count at this site is 24-32 and the RQD estimated from the volumetric joint count is $10-36 \%$. The spacing of the joints on an average ranges from $2-42 \mathrm{~cm}$. The joint walls have an aperture ranging from 0-10 mm. The calculated RMR value for this site is 45 that falls under fair rock quality. Kinematic analysis of discontinuity planes and their intersections (Fig. 4) with respect to slope face indicates that there is possibility of topple failure along joint plane $68^{\circ} / \mathrm{N} 65^{\circ} \mathrm{E}(\mathrm{J} 1)$. The SMR value calculated from the potential failure of planes is 36.5. The rock mass of the site is in bad condition and unstable and falls in Class IV with probability of failure of $60 \%$.

\section{S11:}

The volumetric joint count at this site is 17-25 and the RQD estimated from the volumetric joint count is $33-59 \%$.The spacing of the joints on an average ranges from 12-80 cm. The joint walls have an aperture ranging from $0-10 \mathrm{~mm}$. The calculated RMR value for this site is $\mathbf{5 0}$ that falls under fair rock quality. Kinematic analysis of discontinuity planes and their intersections with respect to slope face indicates that there is possibility of wedge failure by the intersection of joint planes $75^{\circ} / \mathrm{S} 80^{\circ} \mathrm{W}$ (J1) and $35^{\circ} / \mathrm{N} 50^{\circ} \mathrm{W}$ (J2). The SMR value calculated from the potential failure of planes is 44.7. The rock mass of the site is normal and in partially stable condition. The site falls in Class III and the probability of failure is $40 \%$.

\section{S12:}

The volumetric joint count at this site is 15-27 and the RQD estimated from the volumetric joint count is $26 \%$ to $65 \%$. The spacing of the joints on an average ranges from 8-75 $\mathrm{cm}$. The joint walls have an aperture ranging from $0-10$ $\mathrm{mm}$. The calculated RMR value for this site is 53 that falls under fair rock quality. Kinematic analysis of discontinuity planes and their intersections with respect to slope face indicates that there is possibility of plane failure along joint plane $39^{\circ} / \mathrm{N} 45^{\circ} \mathrm{W}(\mathrm{J} 2)$ and wedge failure by the intersection of joint planes $72^{0} / \mathrm{S} 75^{\circ} \mathrm{W}(\mathrm{J} 1)$ and $39^{\circ} / \mathrm{N} 45^{\circ} \mathrm{W}(\mathrm{J} 2)$. The SMR value calculated from the potential failure of planes is 15.3 and 7.65 with an average value of 20.5. The rock mass of the site is in bad condition and unstable, and the site falls in Class IV with probability of failure of $90 \%$.

Table.1: Showing joint and slope orientation data collected from field.

\begin{tabular}{|c|c|c|c|c|c|c|}
\hline \multirow[t]{2}{*}{ Site no. } & \multirow[t]{2}{*}{$\begin{array}{l}\text { Slope orientation } \\
\text { DA/Strike } \\
\end{array}$} & \multicolumn{4}{|c|}{$\begin{array}{c}\text { Joint orientation } \\
\text { DA/DD }\end{array}$} & \multirow[t]{2}{*}{ Mode of failures } \\
\hline & & $\mathrm{J} 1$ & $\mathrm{~J} 2$ & J3 & $\mathrm{J} 4$ & \\
\hline S1 & $80^{\circ} / \mathrm{N} 30^{\circ} \mathrm{E}$ & $55^{0} / \mathrm{N} 65^{0} \mathrm{E}$ & $42^{0} / S 70^{0} \mathrm{~W}$ & $67^{0} / \mathrm{N}$ & - & W-J1\&J3 \\
\hline S2 & $85^{\circ} / \mathrm{N} 30^{\circ} \mathrm{E}$ & $53^{0} / \mathrm{N} 75^{0} \mathrm{E}$ & $45^{\circ} / \mathrm{S} 80^{\circ} \mathrm{W}$ & $72^{0} / \mathrm{N} 05^{0} \mathrm{E}$ & - & W-J1\&J3 \\
\hline S3 & $45^{0} / \mathrm{S} 20^{0} \mathrm{~W}$ & $65^{0} / \mathrm{N} 75^{0} \mathrm{E}$ & $59^{0} / \mathrm{S} 65^{0} \mathrm{~W}$ & $54^{0} / \mathrm{S}$ & $59^{0} / \mathrm{N}$ & P-J3 \\
\hline S4 & $65^{0} / \mathrm{S} 55^{0} \mathrm{~W}$ & $58^{0} / \mathrm{N} 70^{0} \mathrm{E}$ & $62^{0} / \mathrm{N} 80^{\circ} \mathrm{W}$ & $61^{0} / \mathrm{S} 10^{0} \mathrm{~W}$ & - & W-J2\&J3,T-J1 \\
\hline S5 & $85^{\circ} / \mathrm{S} 50^{\circ} \mathrm{W}$ & $55^{\circ} / \mathrm{N} 85^{\circ} \mathrm{E}$ & $45^{\circ} / \mathrm{N} 70^{\circ} \mathrm{W}$ & $52^{0} / \mathrm{S} 10^{0} \mathrm{~W}$ & - & W-J2\&J3 \\
\hline S6 & $85^{\circ} / \mathrm{S} 60^{\circ} \mathrm{W}$ & $54^{0} / \mathrm{N} 75^{0} \mathrm{E}$ & $10^{\circ} / \mathrm{N} 75^{\circ} \mathrm{W}$ & $76^{0} / \mathrm{S} 05^{0} \mathrm{~W}$ & $50^{\circ} / \mathrm{S} 45^{0} \mathrm{~W}$ & W-J3\&J4,T-J1 \\
\hline S7 & $85^{\circ} / \mathrm{S} 65^{0} \mathrm{~W}$ & $68^{0} / \mathrm{N} 60^{\circ} \mathrm{E}$ & $68^{0} / \mathrm{N} 70^{0} \mathrm{~W}$ & $60^{\circ} / \mathrm{S}$ & - & W-J2\&J3,T-J1 \\
\hline S8 & $85^{\circ} / \mathrm{S} 65^{0} \mathrm{~W}$ & $68^{0} / \mathrm{N} 60^{0} \mathrm{E}$ & $68^{0} / \mathrm{N} 70^{0} \mathrm{~W}$ & $60^{\circ} / \mathrm{S}$ & - & W-J2\&J3,T-J1 \\
\hline
\end{tabular}




\begin{tabular}{|c|c|c|c|c|c|c|}
\hline S9 & $85^{0} / \mathrm{S} 50^{0} \mathrm{~W}$ & $74^{0} / \mathrm{N} 60^{\circ} \mathrm{E}$ & $38^{0} / \mathrm{N} 40^{\circ} \mathrm{W}$ & $32^{0} / \mathrm{S} 20^{0} \mathrm{~W}$ & - & T-J1 \\
\hline S10 & $75^{0} / \mathrm{S} 85^{0} \mathrm{~W}$ & $68^{0} / \mathrm{N} 65^{0} \mathrm{E}$ & $42^{0} / \mathrm{N} 50^{0} \mathrm{~W}$ & $35^{0} / \mathrm{S} 23^{0} \mathrm{~W}$ & - & T-J1 \\
\hline S11 & $85^{\circ} / \mathrm{N} 30^{0} \mathrm{~W}$ & $75^{\circ} / \mathrm{S} 80^{0} \mathrm{~W}$ & $35^{\circ} / \mathrm{N} 50^{0} \mathrm{~W}$ & $28^{0} / \mathrm{S} 05^{0} \mathrm{~W}$ & - & W-J1\&J2 \\
\hline S12 & $80^{0} / \mathrm{N} 25^{0} \mathrm{~W}$ & $72^{0} / \mathrm{S} 75^{0} \mathrm{~W}$ & $39^{0} / \mathrm{N} 45^{0} \mathrm{~W}$ & $33^{0} / \mathrm{S} 10^{0} \mathrm{~W}$ & - & W-J1\&J2,P-J2 \\
\hline
\end{tabular}

Table.2: Rock mass rating values obtained at different locations in the study area.

\begin{tabular}{|c|c|c|c|c|c|c|c|c|c|}
\hline $\begin{array}{l}\text { Site } \\
\text { No. }\end{array}$ & Location & $\begin{array}{c}\text { Point } \\
\text { Load } \\
\text { Strength } \\
\text { Rating } \\
\end{array}$ & $\begin{array}{c}\text { RQD } \\
\text { (from } \\
\text { Jv } \\
\text { Rating) } \\
\end{array}$ & $\begin{array}{c}\text { Joint } \\
\text { Spacing } \\
\text { Rating } \\
\end{array}$ & $\begin{array}{c}\text { Joint } \\
\text { Condition } \\
\text { Rating } \\
\end{array}$ & $\begin{array}{c}\text { Groundwater } \\
\text { Condition } \\
\text { Rating } \\
\end{array}$ & $\begin{array}{l}\text { RMR } \\
\text { Value }\end{array}$ & $\begin{array}{c}\text { Class } \\
\text { number }\end{array}$ & $\begin{array}{l}\text { Rock mass } \\
\text { description }\end{array}$ \\
\hline 1 & $\begin{array}{c}33^{0} 09^{\prime} \\
16.4^{\prime \prime} \mathrm{N} \text { and } \\
75^{0} 20^{\prime} \\
36.1^{\prime \prime} \mathrm{E} . \\
\end{array}$ & 7 & 8 & 5 & 10 & 15 & 45 & III & Fair rock \\
\hline 2 & $\begin{array}{l}\text { Lat. } 33^{0} 09^{\prime} \\
18.4^{\prime \prime} \mathrm{N} \text { and } \\
\text { Log. } 75^{0} 20^{\prime} \\
\text { 25.1'E. }\end{array}$ & 7 & 8 & 8 & 10 & 15 & 48 & III & Fair rock \\
\hline 3 & $\begin{array}{c}\text { latitude of } 33^{0} \\
09^{\prime} 47.5^{\prime} \mathrm{N} \\
\text { and longitude } \\
75^{0} 19^{\prime} \\
41.2^{\prime} \mathrm{E} \text {. }\end{array}$ & 7 & 13 & 10 & 10 & 15 & 55 & III & Fair rock \\
\hline 4 & $\begin{array}{l}\text { Lat. } 33^{0} 09 ' \\
49.0^{\prime}{ }^{\prime} \mathrm{N} \text { and } \\
\text { Log. } 75^{0} 19 \text { ' } \\
38.6^{\prime} \mathrm{E} \text {. }\end{array}$ & 7 & 13 & 5 & 10 & 15 & 50 & III & Fair rock \\
\hline 5 & $\begin{array}{l}\text { Lat. } 33^{0} 09^{\prime} \\
54.2^{\prime \prime} \mathrm{N} \text { and } \\
\text { Log. } 75^{0} 19^{\prime} \\
\text { 31.4'E. }\end{array}$ & 7 & 13 & 8 & 10 & 15 & 53 & III & Fair rock \\
\hline 6 & $\begin{array}{l}\text { Lat. } 33^{0} 09^{\prime} \\
58.3^{\prime \prime} \mathrm{N} \text { and } \\
\text { Log. } 75^{0} 19^{\prime} \\
\text { 27.1'E. }\end{array}$ & 7 & 8 & 8 & 10 & 15 & 48 & III & Fair rock \\
\hline 7 & $\begin{array}{l}\text { Lat. } 33^{0} 10^{\prime} \\
03.9^{\prime} \mathrm{N}^{\prime} \text { and } \\
\text { Log. } 75^{0} \\
19^{\prime} 17.2^{\prime \prime} \mathrm{E} \text {. }\end{array}$ & 7 & 13 & 8 & 10 & 15 & 51 & III & Fair rock \\
\hline 8 & $\begin{array}{c}\text { Lat. } 33^{0} 10^{\prime} \\
07.4^{\prime \prime} \mathrm{N} \text { and } \\
75^{0} 19^{\prime} 09.5^{\prime} \mathrm{E} \\
\end{array}$ & 7 & 13 & 8 & 10 & 15 & 51 & III & Fair rock \\
\hline 9 & $\begin{array}{l}\text { Lat. } 33^{0} 10^{\prime} \\
21.3^{\prime \prime} \mathrm{N} \text { and } \\
\text { Log. } 75^{0} 18^{\prime} \\
\text { 45.9”E } \\
\end{array}$ & 7 & 8 & 5 & 10 & 15 & 45 & III & Fair rock \\
\hline 10 & $\begin{array}{l}\text { Lat. } 33^{0} 10^{\prime} \\
36.2^{\prime \prime} \mathrm{N} \text { and } \\
\text { Log. } 75^{0} 18^{\prime} \\
\text { 49.2”E }\end{array}$ & 7 & 8 & 5 & 10 & 15 & 45 & III & Fair rock \\
\hline 11 & $\begin{array}{c}\text { Lat. } 33^{0} 10^{\prime} \\
45.2^{\prime \prime} \mathrm{N} \text { and } \\
\text { Log. } \\
75^{0} 18^{\prime} 52.66^{\prime \prime E} \text {. }\end{array}$ & 7 & 13 & 5 & 10 & 15 & 50 & III & Fair rock \\
\hline 12 & $\begin{array}{c}\text { Lat. } 33^{0} 10 ' \\
56.1^{\prime}{ }^{\prime} \mathrm{N} \text { and } \\
\text { Log. } 75^{0} 18 ' \\
51.6 ” \mathrm{E}\end{array}$ & 7 & 13 & 8 & 10 & 15 & 53 & III & Fair rock \\
\hline
\end{tabular}


Kinematic Analysis of the Dam and Powerhouse Sites of the Baglihar Hydropower Project

Table.3: Showing SMR results obtained from the study area with mode of observed failure.

\begin{tabular}{|c|c|c|c|c|c|c|}
\hline $\begin{array}{l}\text { Site } \\
\text { No. }\end{array}$ & Location & $\begin{array}{l}\text { SMR } \\
\text { values }\end{array}$ & Observed failure & $\begin{array}{l}\text { Slope } \\
\text { description }\end{array}$ & Class No. & Probability failure \\
\hline 1. & $\begin{array}{l}33^{0} 09^{\prime} 16.4^{\prime} \times \mathrm{N} \\
\text { and } 75^{0} 20^{\prime} \\
36.1^{\prime \prime E} \text {. }\end{array}$ & 20 & Wedge failure & $\begin{array}{l}\text { Completely } \\
\text { unstable }\end{array}$ & $\mathrm{V}$ & 0.9 \\
\hline 2. & $\begin{array}{l}\text { Lat. } 33^{0} 09 \text { ' } 18.4^{\prime \prime} \mathrm{N} \\
\text { and Log. } 75^{0} \quad 20^{\prime} \\
\text { 25.1"E. }\end{array}$ & 40 & Wedge failure & Unstable & IV & 0.6 \\
\hline 3. & 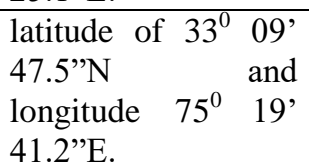 & 12 & Plane failure & $\begin{array}{l}\text { Completely } \\
\text { unstable }\end{array}$ & $\mathrm{V}$ & 0.9 \\
\hline 4. & $\begin{array}{l}\text { Lat. } 33^{\circ} \quad 09^{\prime} \\
49.0{ }^{\prime} \mathrm{N} \text { and Log. } \\
75^{\circ} 19^{\prime} 38.6 \text { "E. }\end{array}$ & 20.5 & $\begin{array}{l}\text { Wedge/Topple } \\
\text { failure }\end{array}$ & Unstable & IV & 0.6 \\
\hline 5. & $\begin{array}{l}\text { Lat. } 33^{0} 09^{\prime} 54.2^{\prime \prime} \mathrm{N} \\
\text { and Log. } 75^{0} \quad 19^{\prime} \\
\text { 31.4"E. }\end{array}$ & 21.6 & Wedge failure & Unstable & IV & 0.6 \\
\hline 6. & $\begin{array}{l}\text { Lat. } 33^{0} 09^{\prime} 58.3^{\prime \prime} \mathrm{N} \\
\text { and Log. } 75^{\circ} 19^{\prime} \\
27.1 \text { 'E. }\end{array}$ & 31.3 & $\begin{array}{l}\text { Wedge/Topple } \\
\text { failure }\end{array}$ & Unstable & IV & 0.6 \\
\hline 7. & $\begin{array}{l}\text { Lat. } 33^{0} \quad 10^{\prime} \\
03.9^{\prime} \times \mathrm{N} \text { and Log. } \\
75^{\circ} 19^{\prime} 17.2^{\prime \prime E} \text {. }\end{array}$ & 28.65 & Wedge Topple & Unstable & IV & 0.6 \\
\hline 8. & $\begin{array}{ll}\text { Lat. } 33^{0} & 10^{\prime} \\
07.4^{\prime} \times \mathrm{N} & \text { and } \\
75^{0} 19^{\prime} 09.5^{\prime} \mathrm{E} & \end{array}$ & 28.65 & Wedge/Topple & Unstable & IV & 0.6 \\
\hline 9. & $\begin{array}{l}\text { Lat. } 33^{\circ} \quad 10^{\prime} \\
21.3^{\prime \prime} \mathrm{N} \text { and Log. } \\
75^{\circ} 18^{\prime} 45.9^{\prime \prime} \mathrm{E}\end{array}$ & 35 & Topple & Unstable & IV & 0.6 \\
\hline 10. & $\begin{array}{l}\text { Lat. } 33^{\circ} \quad 10^{\prime} \\
36.2^{\prime \prime} \mathrm{N} \text { and Log. } \\
75^{\circ} 18^{\prime} 49.2^{\prime \prime} \mathrm{E}\end{array}$ & 36.5 & Topple & Unstable & IV & 0.6 \\
\hline 11. & $\begin{array}{l}\text { Lat. } 33^{0} 10^{\prime} \\
45.2^{\prime \prime} \mathrm{N} \text { and Log. } \\
75^{0} 18^{\prime} 52.6^{\prime} \mathrm{E} \text {. }\end{array}$ & 44.7 & Wedge & Partially stable & III & 0.4 \\
\hline 12. & $\begin{array}{l}\text { Lat. } 33^{0} \quad 10^{\prime} \\
56.1^{\prime} \mathrm{N} \text { and Log. } \\
75^{\circ} 18^{\prime} 51.6{ }^{\prime \prime} \mathrm{E}\end{array}$ & 11.48 & Wedge/Plane & $\begin{array}{l}\text { Completely } \\
\text { unstable }\end{array}$ & $\mathrm{V}$ & 0.9 \\
\hline
\end{tabular}


S1
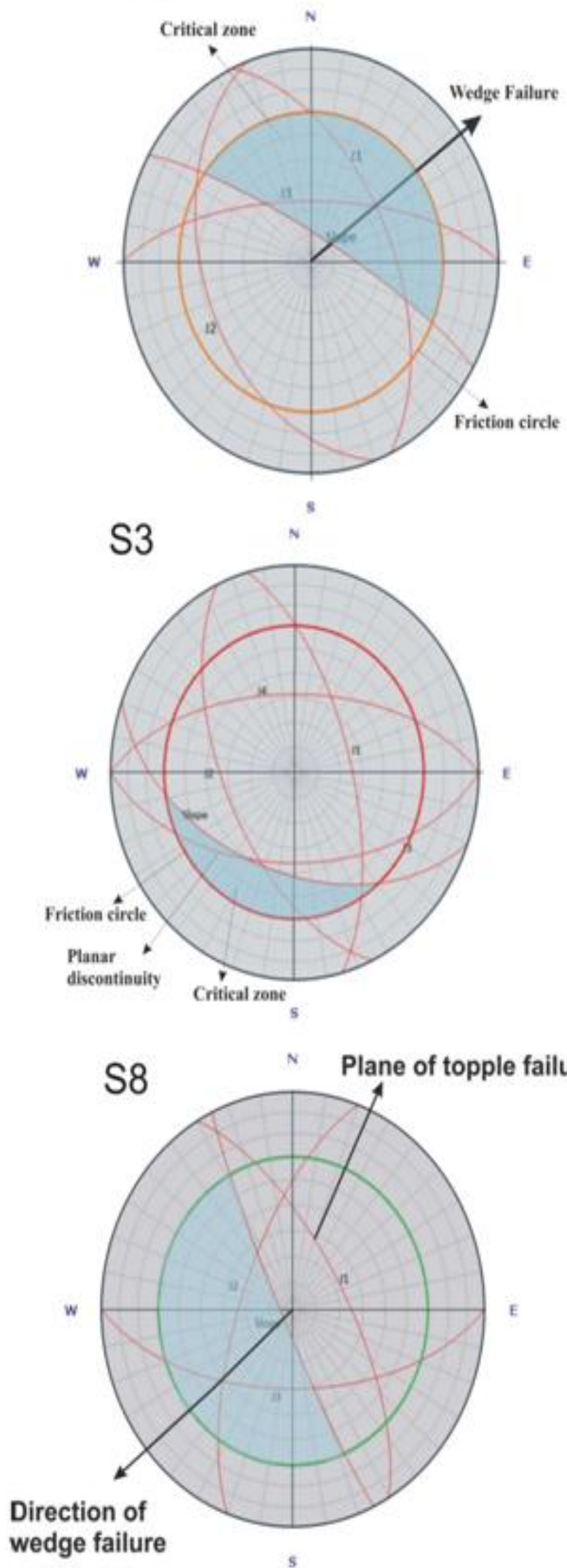

S2
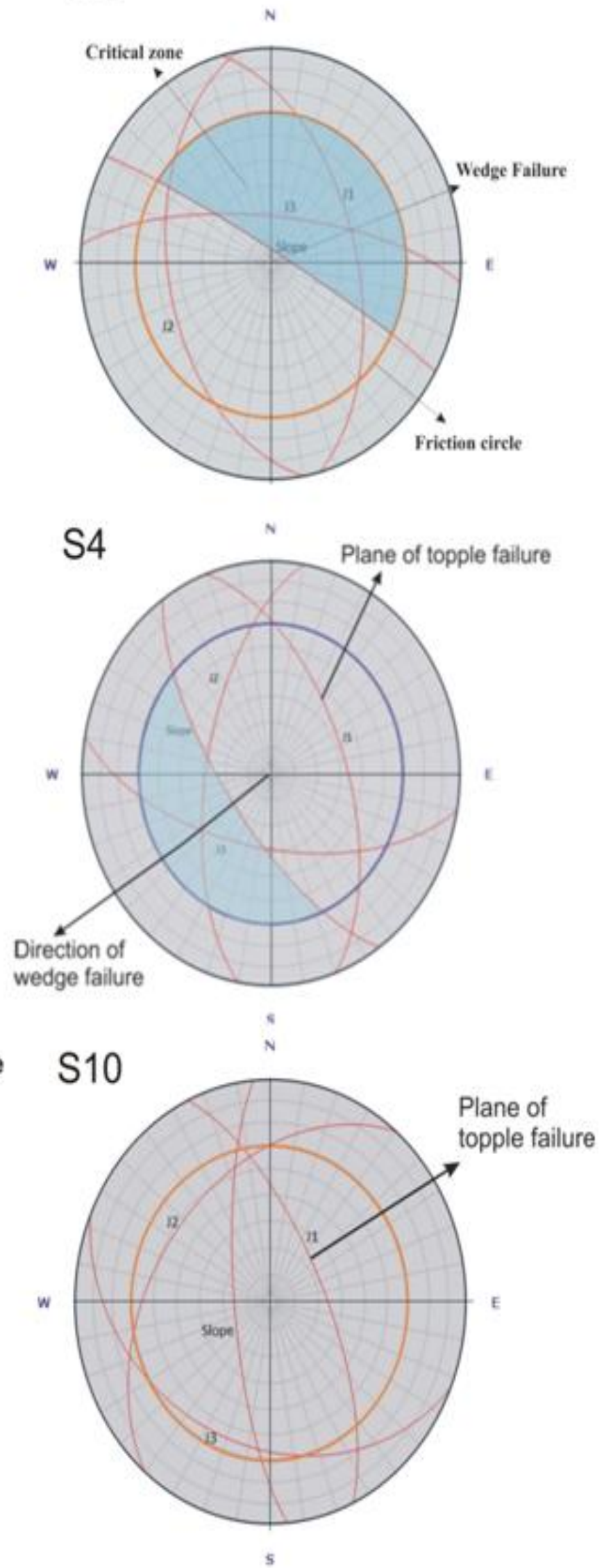

Fig.4: Stereographic projection plots of few unstable and completely unstable classes in the study area.

Retrieval Number: A3949119119/2020@BEIESP DOI: 10.35940/ijitee.A3949.019320 Journal Website: www.ijitee.org
Published By:

Blue Eyes Intelligence Engineering \& Sciences Publication (BEIESP)

(C) Copyright: All rights reserved.

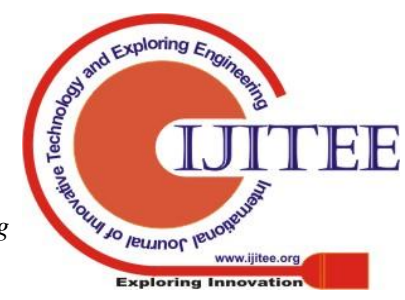




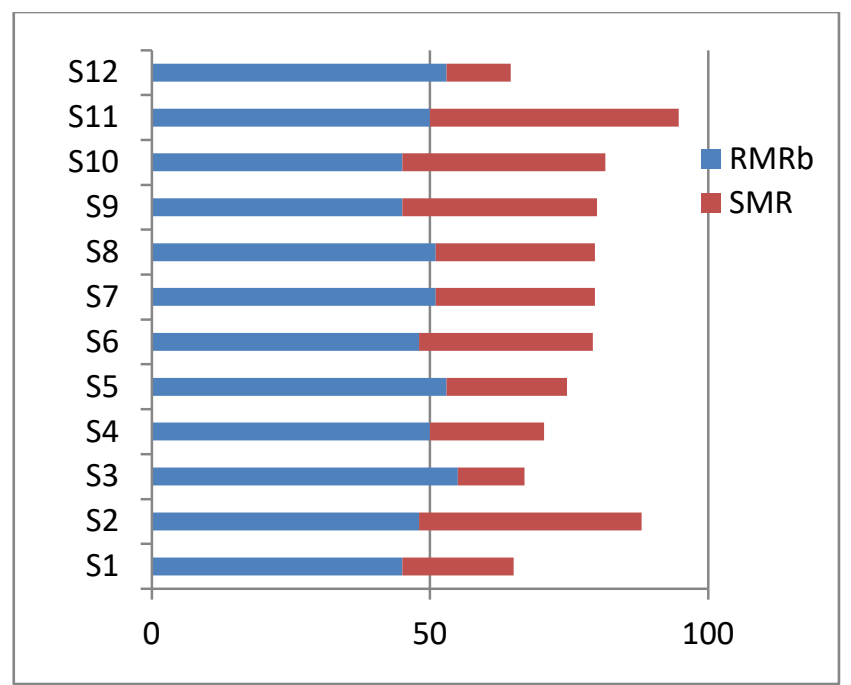

Fig.5: The diagram showing comparison between observed RMR and SMR values of different sites in study area.

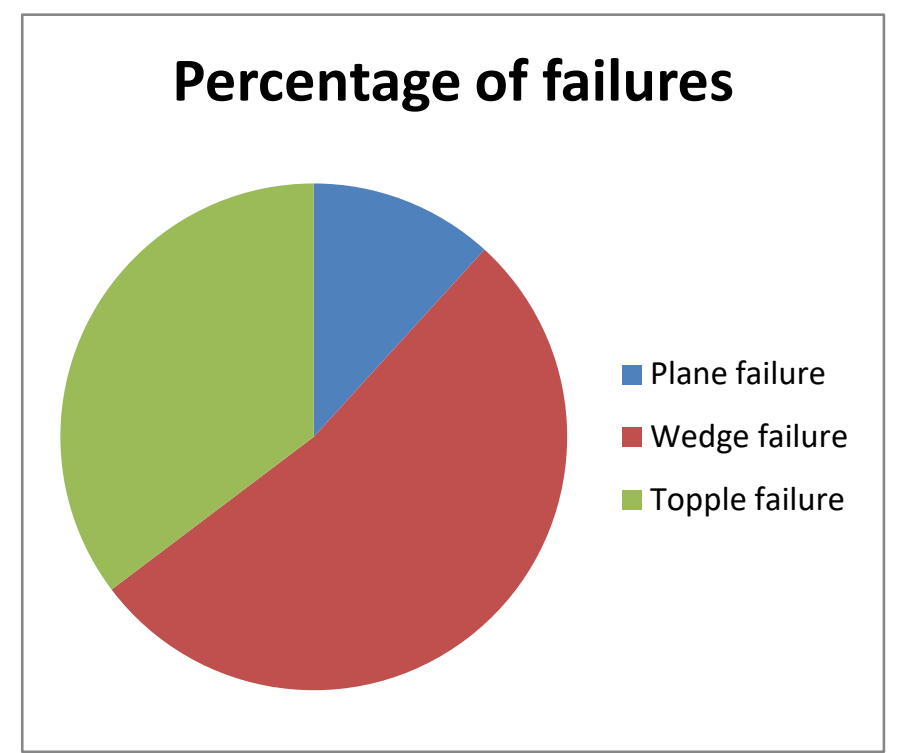

Fig.6: The given chart showing percentage of different failure in the study area.

\section{DISSCUSSION \& CONCLUSION}

Using joint data, analysis for rock mass rating (Table 2) and slope mass rating (Table 3) was done. We observed point load strength has same value for all sites having same rock type with rating of 7 (Table 2). The RQD rating varies from 7 to 13 (Table 2). The RMR value varies from rating 45 to 55 (Table 2) and rating values reveals that all the sites fall under the fair quality rocks (Class-III). SMR results reveal that our sites fall under the three stability classes that are Class III, Class IV and Class V (Table 3). We compared the results of RMR and SMR and found that rock slope stability clearly depends on the joint orientation, angle of slope and rock friction angle and, slope stability is independent of rock mass rating. While comparing the observations of rock mass rating and slope mass rating (Fig. 5) we found that the sites with fair quality of rocks (on basis of RMRb) tend to be unstable to completely unstable (on the basis of SMR scheme). According to SMR values, eight sites (S2, S4, S5, S6, S7, S8, S9 and S10) are unstable (Class-IV), three sites
(S1, S3 and S12) are completely unstable (Class-V), and one site (S11) is partially stable (Class-III). The kinematic analysis reveals that at each site, joint intersects with each other on slope and form potential failure sites where nine sites (S1, S2, S4, S5, S6, S7, S8, S11, S12) are susceptible to wedge failure (Fig. 2c), six sites (S4, S6, S7, S8, S9, S10) are susceptible to topple failure, and two sites (S3 and S12) are likely to plane failure (Fig. 2a) and percentage of category-wise failure sites are shown in Figure 6. The rock slope failure occurring in the fair rock category may be assigned to mechanical excavation activity along the road leading to the dam site, although the contribution from highly jointed rocks (Fig.2b) due to tectonic activity cannot be ruled out.

\section{ACKNOWLEDGMENT}

The authors are grateful to the Department of Geology, University of Jammu for providing necessary facilities to carry out this research.

\section{REFERENCES}

1. Bhatia, T. R., \& Bhatia, S. K. (1973). Sedimentology of the slate belt of Ramban-Banihal area, Kashmir Himalaya. Him. Geology, vol. 3, (pp. 116-134)

2. Bieniawski, Z. T. (1989). Engineering rock mass classifications: a complete manual for engineers and geologists in mining, civil, and petroleum engineering. John Wiley \& Sons.

3. Haq, A. ul., Pandita, S. K., Singh, Y., Bhat, G. M., Pandey, S. J., Singh, A., ... \& Bansal, B. K. (2019). Evidence of Active Tectonic Deformation in Kishtwar Area, Jammu and Kashmir, Northwest Himalaya, India. Journal of the Geological Society of India, vol. 93(3), (pp.331-342)

4. Jangpangi, B. S., Kumar, G., Rathore, D. R., \& Dutta, S. A. B. I. R. (1986). Geology of the 'Autochthonous Folded Belt', Jammu \& Kashmir Himalaya with special reference to the Panjal Thrust. Journal Palaeontological Society of India, vol. 31, (pp.39-51).

5. Romana M, (1985). New adjustment ratings for application of Bieniawaski classification to slopes. Int Symp on the role of rock mech, ISRM. Zacatecas, (pp. 49-53).

6. Sharma, V. P., Chaturvedi, R. K., \& Sundaram, R. (1975). Langera conglomerate and its correlation with other conglomeratic formations of the Himalaya. Bull. Ind. Geol. Assoc, vol. 8(2) (pp.106-112).

7. Wadia, D.N, (1931). The syntaxis of the north-west Himalaya: its rocks, tectonics and orogeny. - Rec. Geol. Surv. Ind., vol. 65 (2), (pp.189-220).

8. Bolt, B. A., Horn, W. L., Macdonald, G. A., \& Scott, R. F. (1975) Hazards from earthquakes. In Geological Hazards. Springer, Berlin, Heidelberg, (pp.1-62)

9. Goodman R.E, (1989). Introduction to rock mechanics, 2nd edn. Wiley, New York

10. Gupta, V., \& Shah, M. P. (2008). Spatial variability of mass movements in the Satluj Valley, Himachal Pradesh during 1990 2006. Journal of Mountain Science, vol. 5(1), (pp.38-51).

11. Hoek, E., \& Bray, J. D. (1981). Rock slope engineering. CRC Press.

12. Palmstrom. A, (2005). Measurements of and correlations between block size and rock quality designation (RQD). Tunnelling and Underground Space Technology, vol. 20(4), (pp.362-377).

13. Singh, P., Ramanathan, A.S., Ghanekar, V.G., (1974). Flash floods in India. International Association of Hydrological Science vol. 112, (pp.114-118)

14. Singh, Y., Bhat, G. M., Sharma, V., Pandita, S. K., \& Thakur, K. K. (2012). Reservoir induced landslide at Assar, Jammu and Kashmir: a case study. Journal of the Geological Society of India, vol. 80(3), (pp.435-439).

15. Sundriyal, Y.P., Tripathi, J.K., Sati, S.P., Rawat, G.S., Srivastava, P., (2007). Landslide dammed lakes in the Alaknanda basin, lesse Himalaya: causes and implications. Current Science vol. 93 (4), (pp 568).

Published By:

Blue Eyes Intelligence Engineering

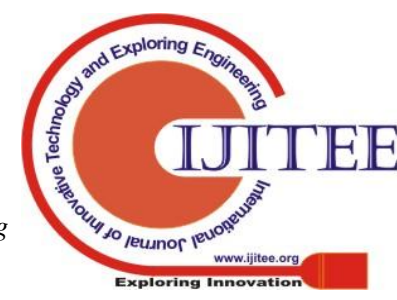




\section{AUTHORS PROFILE}

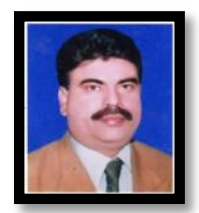

Mr. Romesh Kumar, is presently working as an Engineering Geologist in the Jammu and Kashmir Power Development Corporation (JKPDC). He is pursing Ph.D in Geotechnical and structural aspects of Baghliar Hydroelectric power project, from University of Jammu, Jammu.

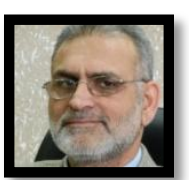

Dr. G.M Bhat, is presently working as professor in the Department of Geology, University of Jammu, Jammu. He has 102 publications in the national and international journals. $\mathrm{He}$ is working on sedimentology, structural and engineering Geology, seismology and Hydrocarbons. He is YMS awardee 1999 in physical sciences, Global Getererg Awardee-2010 and S.V Naqvi Gold Medal awardee 2019 in recognition to his valuable contribution to the Geology of India.

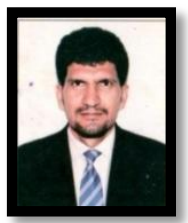

Dr. Yudhbir Singh, is presently working as an Assistant Professor at University of Jammu. He is teaching in this department from last 10 years and has published 31 research papers and 3 books in the national and International Journals. He is J\&K young scientist awardee 2010 .

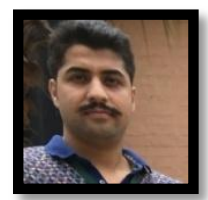

Mr. Arjun Singh, is pursuing Ph.D in Geodynamic studies in NW Himalayas via GPS from University of Jammu, Jammu. During his M.Phil he worked on "Rock mechanics and slope stability". He is also working as Senior Research Fellow in a seismology project entitled "Crustal Deformation Studies in Jammu and Kashmir" funded by the Ministry of Earth Sciences at University of Jammu, Jammu.

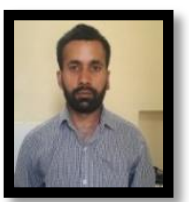

Dr. Ahsan Ul Haq, has completed Ph.D in Geology from university of Jammu, Jammu and is presently working as senior research fellow in seismology project entitled "Seismic Hazard Assessment in the Kashmir Himalaya, using, geological, seismological and geodetic data" funded by the Ministry of Earth Sciences, Government of India at university of

Jammu, Jammu. 